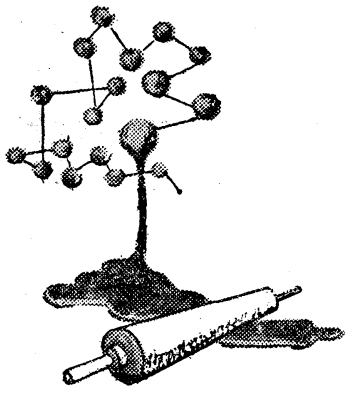

印别インキの製造原粦に，高分子物が多種頑にわたっ て利用されて特り，印刷技幑が進步すればす尽程，一層 進步した新しい型厅印刷インキが翣求せられて，特に合 成高分子物が，盛んに使用されることが予想される。例 えば, 印別のスピード化によって，從来の型のインキが ヒートセットインキに切り換えられるので, これに特殊 な印刷インキ用合成樹脂が使用される。しかも，大印刷 会社が, 競って，大部数の印刷物に使用する印刷インキ をこの型のものに切り換えて，印刷能卒ををげるといら

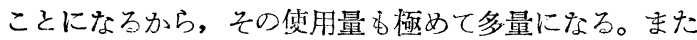
普通の印勋インキでも，印刷機械こよって印刷された印 刷インキの皮膜は，通常は準高分子か高分子と考えられ る場合が多いので，印刷インキと高分子化学との関連性 は，極めて密接不可分のものである。殊に，従来酸素の 存在によるか，またはこれなしに，重合あるいは縮合す る媒質を使用すを印刷インキは，最も重要な型のもの であって，植物または動物性乾性油を主体としてつくっ たものであるが，この種のインキの乾燥性を增加し，イ ンキ皮膜の強さを向上し，印刷された物質の面との接着 力を習大するなどの目的でも合成樹脂が利用される。こ のよらに，合成樹脂の化学の発達と共に，これら合成高 分子物が大いにこの分野に採り容れられるよ5になっ た。また，澱粉，繊維素などの炭水化物，弾性ゴムのよ らな炭化水素といった高分子物も，この分野に応用せ られているのであって，天然高分子物の利用範围む広い ので女る。けれども，どのよ5な高分子物が，どのよ 5 な印刷方式の印剧インキ用材料として，適当であろらか といらことは，極めて複雑な条件によってきめられるの でもる。何故かといえば，少くとも印刷インキといらも のは，印刷對械こよって被印刷物(紙とふ，金属板とか ビニルシートとかいらよらに上上，印刷され得るため には、その印刷インキに「印刷適性」といら語で岕らわさ 凡る適性が必妿となって来るのでるる。例えば, 整料と 印刷インキは，その組成については，非常に近似ててい

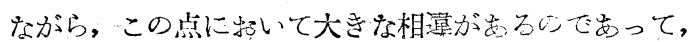
征って整粼用原料として使用し得る高分子制ぶ, 印勋厂 ンキ用としては使用し得なかったり，集用し得るとして
展 望

\section{キ と高分子}

塩

冶

孜

も多名特殊の印别方式に使用範罒が限定せられるといっ たような，面倒なことが起るのを一ー一例で女る。この よらな場合を例示するならば，油溶性不眾酸樹脂は，平 版オフセットインキ用に使用できるが，ポリビニルアセ テートは，非常に使用困難であり，これはグラビア用イ ンキには使用乙得るといらよらなことでまる。これは, 油溶性不炭酸樹脂を使用して製造した印别インキ用ビヒ クル (媒質) は, 电系性, 弹性, 粘着性などが平版印别 インキの流動学的適性に合致するのでをるが，ポリビ二 ルアセテートの場合には，曳糸性はあっても，弾性その

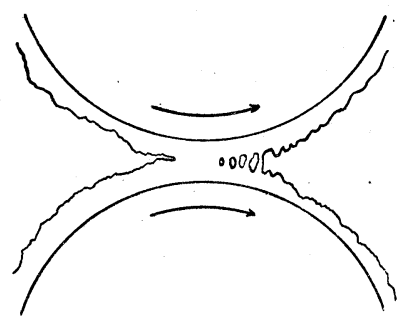

[文献]=Lars H.Sjodahl, American Inkmaker Vol. 39, No.3 p31 (1951)
左図は二つの週転口一 ラー上のインキの流動 状㦘を示す断面図であ る。乙の状䔮は印刷中 に扑ける種々の場合例 えば, 印㴊インキを版 面につけるローラーと 円筒状の版面, ブラン ケットをはった円筒と 版面，ブランケットを 印刷される紙つ表面と の掕触部に扎ける各種 の場合を通じて，大体

同じょらな状熱を示するのと考えてょく，乙れを代表す る困と洘えればよかる5。

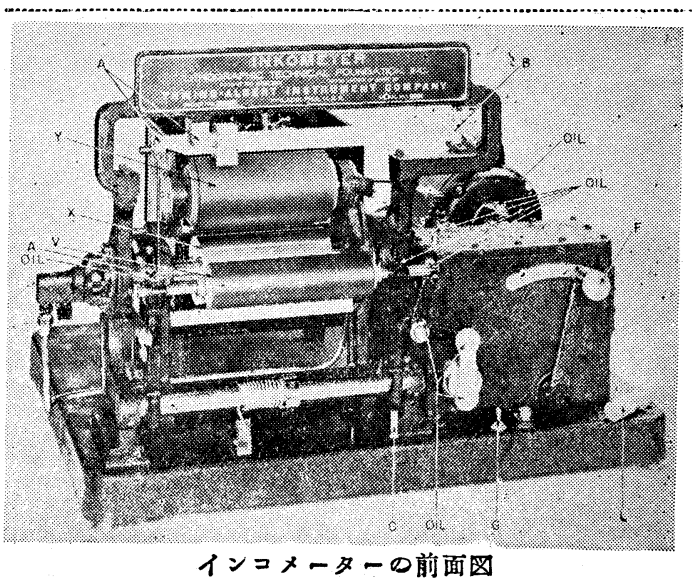




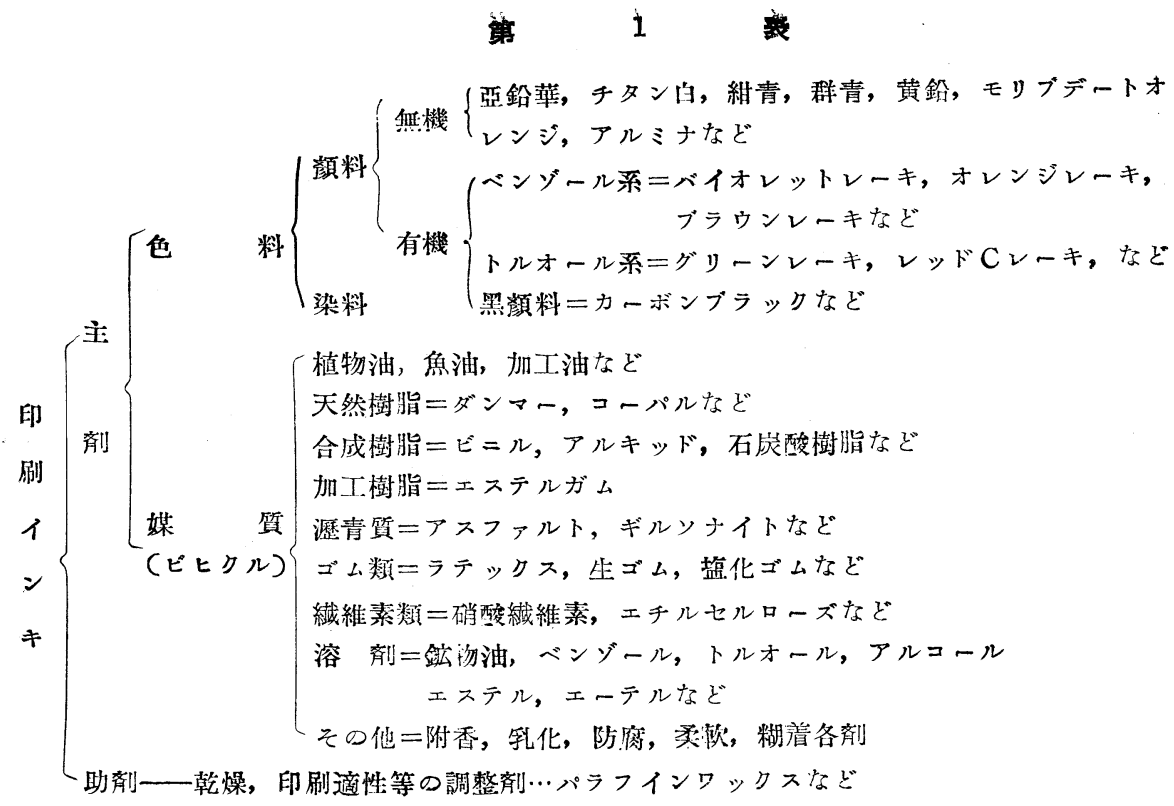

他の性状が，平版インキ用には不適当であり，曳系度も 過度の嫌いがある。このよらに，閒題になるのは，印别 インキ特有の Consistency (稠度)である。印刷イ ンキは, 顏料 (色料つ一種) とビヒクルと称する媒質と を緊密に練り合せたもので女るがこのビヒクルの後目 は，インキをして円滑に印別機中を流䎐し，版面に展閉 する性質を与え，印刷後，紙中に漻透し乾固し薄い皮膜 を造って，顏料を紙などの被印别物に固着させ，むるい は保護するにある。従って，印别インキ中のビヒクル中 に高分子物を使用するについても，これによって，印勋 インキの印别適性，紙と版の離れぐあい，紙むけなどの 性質が，十分に良好でなくてはならない1)。Voet 及び Sjodah1 は, 印刷インキの挙動について, Viscoelasticity（粘弹性）といら性質が，相当重視されなくてはな らないことを强調しこのよ5な性質について今まで多 数の研究者が,プラスチックス, 紙, ゴムなどの溶液や 熔融物について研究を行った。

またGreen等は，印刷インキのローラー間にむける流 動学的挙動を2) “Inkometer”といら装置を用いて, 测 定することを試みた。このよらに，印刷インキの物理的 挙動を測定するのに, 特殊の装置を使用することが現在 行われつつまるが、スペチュラを使用して緬ってわ弾性 そ粘性も共に認められるのであって，このよらな性質が 志々限界内に岕る時に適当な印刷インキとしての性状が 要らわれるのである。このよらな見地から，合成樹脂のよ らな合成高分子物を使用寸る場合にも，その融点，雷合 度などをよく考えて選択する必要が生じてくる。例えば 印別インキ用材料として，石炭酸樹脂を採用する場合に は, 印別逗性十分であり，䢧透性少なく，光沢が十分で むるよらな印刷インキをつくるための樹脂は $140^{\circ} \mathrm{O}$ 以上

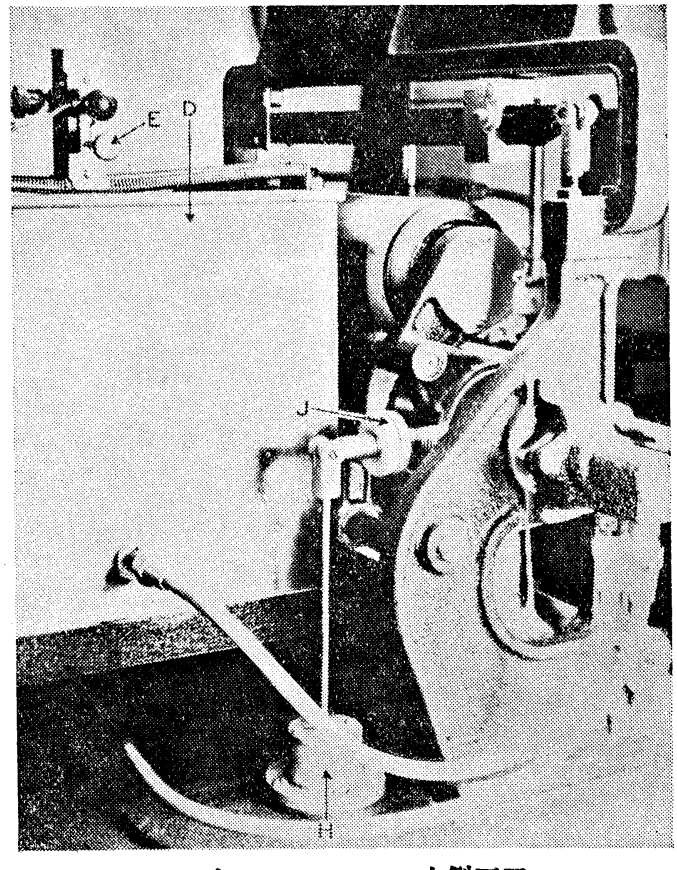

インコメーターの左側面図

の融点のものであることが必要である。

次に各種高分子物質が印刷イン生に，どの上与に店用 されるかを例を示して述べてみると，繊維素類について は, 粘度の低い翌の确酸瀻維素は, 溶剤に対与る繊維素 量多くかつ粘度が低く使用でき，印刷インキ原料として 好適で, 熱乾燥性インキやアニリンインキのワニスとし て使用される。またこれと塩化ゴムを配合することによ って，附着力の良好なる印刷インキができるのである。 エデルセルーズ, メチルセルローズ, 各種つセルロー ズェンテルなどる印别インキに使用せられる。 
ゴム類なる高分子物は、ゴム製品への印别インキとし て使用せられると共に, プラスチックス,レザー製品, 硫酸紙, 金属紙, 特殊紙などへの印別に使用されるなどの 與味をる利用面がある。ゴム類としては, ラテックス, 生ゴム，壏化ゴムなどが使用せられる。

澱粉のよらな高分子物は，糊着郕として，印别インキ のビヒクル中に用いられることは，アラビアゴム，デキ ストリン，カゼインなどと同樣である。その他バラフイ ンのよ5な高分子物も, ビヒクル中に混入して使用され 印刷適性を改良するなどの役目をする。

3)アルキッド樹脂は, 乾燥性がよく, その乾燥した皮膜 が強勒であり，印刷された物質の袁面によく接着し，柔 軟であるなど種々の長所を有しているので, 印刷インキ に応用し得る高分子物中重要なるものであり, 殊に重合 型インキには非常に大切である。米国デトロイドを訪問 して，塗㩽用ならびに印刷インキ用合成樹脂を製造する ライヒホールド化学工業株式会社を見学した私には, こ のアルキッド樹脂が米国において，警くほど多量に生虐 され、またその設犕の大なのに驚かされたが,米国に抏い て, 無水フタル酸の製造量が增加 し, 洒格が低廉となっ て印刷インキ用にもこの樹脂が多量に使用されていたの で,わが国でぜひこれは多量に使用されるよ5な方向 に進む必要があることを痛感した。るちろんフタル酸の みのアルキッドナ゙けではなく, マレイン酸その他の酸を 使用するものも重要である。アルコールについてるグリ セリンのみならず, ペンタエリスリトールも重要であ る。しかして脂肪酸として亜麻仁油を使用し，これを 変型する場合が多く, 西麻仁油を使用したものは平版イ ンキにも凸版インキにも良好な成績を示している。次に 油溶性石炭酸樹脂であるが，これはドイッにおいてコー バル代用として研究されたものだが，ランニングが不 必要であり, 殆んど中性で塩基性顏料とも混合できュー バルより硬度, 耐久性にすぐれている。ワニスの乾燥性 が早く，乾燥皮膜の粘着性がないなどの良好な性質を有 する為、これる印刷インキ用合成樹脂として重要であ る。強光沢を得られるから, 艶インキ用ビヒクルの材料 として使用せられることが多い。その他耐水性大にして 雅アルカリ性飞良好であるから，この方面の特殊インキ ビヒクルの材料としてあ使用せられる。しかしながら石 炭酸樹脂もパラ置換フェノールを使用しないと石炭酸が 酸化せられてパラキノンとなり変色せられるのでこれ が印刷インキの色に影響する為に，淡色の印刷インキ用 ビヒクルとしてはこの点に注意を喿する。尿素樹脂はア ルキッド樹脂と併用してブリキ板用印刷インキに使用し たり，捺染用インキとして使用する場合がある。またア ニリンインキ用としてる使用され得る可能性がある。ま た使用を適切にすれはグラビアインキ用としてむ使用さ れ得る。

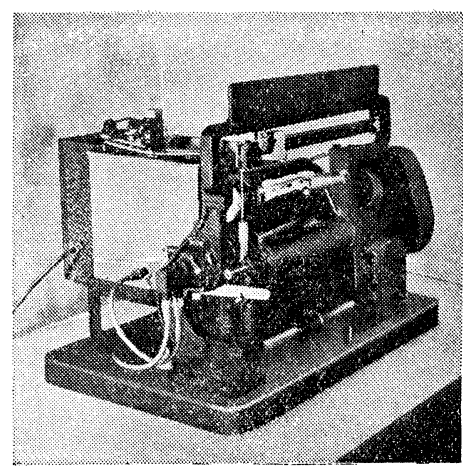

インコメーターに陚料インキを 与える図
次に, 印剧インキ 。楀類から高分子 物の利用について 考えてみると，米 国の印刷業界つ私 の視察つ結果から みると，米国印刷 界の動向は, 要す るにスピード化し て迅速に印勋を行 らことに重点が置 かれて特り，印刷 物の生座量は年々管加する一途にある。これが為印别イ ンキの形態は，何等かの高分子物，一例としては石炭酸 樹脂, マレイン酸樹脂, あるいは瀻維素誘導体などを高 沸点溶洲に溶解し，場合によってはこれに可塑蝺を添加 するといったよらな，いわゆるとートセットインキが盛 んに用いられはじめている。これらは溶蝺が加熱によっ て飛散すると，直に高分子物の皮膜に覆われた顏料が紙 のよらな被印刷物の表面に固着されるといった方式のる のでこれによって徉来の乾性油ワニスでつくったビヒ クルの乾燥性の達い欠点を改良している。かく印刷イン キの型式をヒートセットの型に切り換えた結果, その印 刷速度は $1200 \mathrm{f} / \mathrm{min}$ が可能となっている。例の有名な ライフ誌は五百数十万部を 1 週間に印刷出版しているが このよ5な大部数の雑誌類の印刷は, このヒートセット インキならざれば不可能であろらといわれており,この よらな部面に高分子物の利用方面が開けている。また食 料品つ包装紙印刷の為に使用される印刷インキは, 米国 においてはスチームセットインキを使用しておりこれ る印刷インキがセットする迄に要する時閒は極めて短か い。この種のインキは交献には各種つ用途があるよらに 書かれているが実際には食料唱の包装紙だけかと思った が，在米中パックイジング用厚紙の印刷工場を訪問した 時この印刷インキを使用して，多量に各種の小型パック イジングボックスの印刷を行っているのを見て驚かされ た。何故このインキが食料品の包紙に使用されるかとい らと，印刷インキの臭気が少ないことで，米国では，食 料品特にパン類に印刷インキの臭気がつくことをきら5 為である。このインキは, 印刷された後, 蒸気炑霧状の 水滴を，ノズルから吹きつけるだけで迅速にセットする のであって，印刷速度は毎分 $900 \mathrm{f}$ 位であるといわれ， Moisture Set Ink, Vaposet Ink, Hydry Ink など と種々の商品名で壳り出されている。

これには,マレイン酸,フマル酸樹脂を使用するそいら Michigan Research Laboratories の方法, 尿菜樹脂, メラミン樹脂,繊維素誘道体っアリルスターチなど在使用 する方法などがむる。このよ5に高分子物がこの镭のイ 


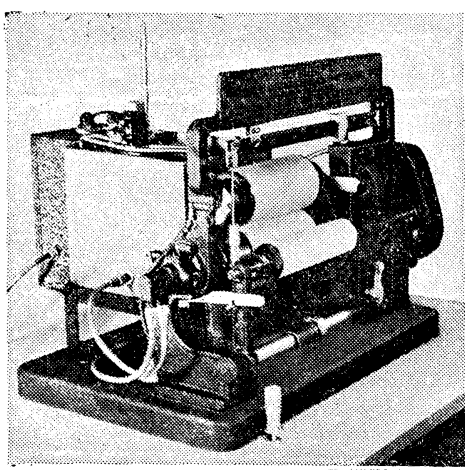

インコメーターでインキの粘着 性測定中の因
ンキにも使われて いるのだ希って, 溶剤はグリコール などでまる。すた 印别後加熱するこ とによって印别イ ンキが迅速にゲル 化して直ちにセッ トするといらもの でオルガノゾル型 のワニスを使用す るので,この為の 合成樹脂はビニル系のもので岕り, 可塑剤にこれを分散 させたものである。凸版用プレッシャーセットインキ4) といらのは“Wink-dry” インキとるいわれ，新しい型 のインキでるる。これは環化ゴム定高沸点炭化水素に分 散させたもので，環化ゴムが溶剂にコロイド状に分散し

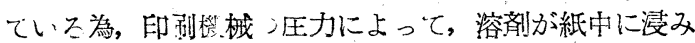
込むと，印别インキがセットするといら方式のインキて ある。また溶偊中に溶解している樹脂が印刷後溶肪の揮 発によって, 重合作用が可能となって, 固化するといっ た乾燥方式をとるものには，スチレン，ブタジェン，ビ ニル采高分子物のモノマーをどが用いられる。かく考え て来ると，ゴム，㵶維素またはビニルのよ5な合成樹脂 など，多種類な高分子物か印别インキに利用されている ことがわうミ。米国では，最近のグラビア印刷には密閉 式が採用せられて怙り，わが国でもダルジヤン法が採り 入れられているので，技術的に極めて急速な進步を示し ている。また印别インキの色つ冴えた，高濃度のものが 要求せられ，殊に多色グラビアとなれば，無色透明なビ ヒクルが劕求せられるのでここの目的に合致するよらな 合成高分子物が使われはじめ，溶绪も密閉式グラビアの 場合は, 高、揮発性つものを集用するのでもる。この為

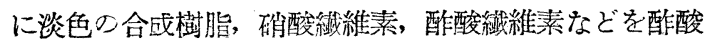

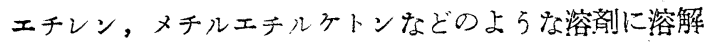
してインキの乾燥を極めて速くしている。また石檢つ包 紙，グラシン紙，セロファン紙その他各種つ紙袋用印别 インキとして，速刷を目的とすをアニリンインキがわが 国で京用いられはじめた。米国ではこれが盛でもって, 将来ます李す需要が增大されよらが，元来これに使用さ れを版面はゴムでもる為に溶㓣にはアルコールが使用さ れる。そしてマレイン酸樹脂, ビニル樹脂, アリルスタ 一チ，硝酸瀻維素なよ゙が市用されている。

以上は印荆インキに種類に上を高分子物て応用につい て述べたので忌が，朄の印跑物が戦後わが国に輸大

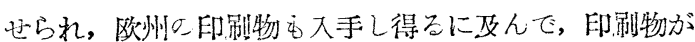
非常に強光尺であること定目の昰たり見たわが国の人々 は，印剓う表面に，強光尺のワニスを塗布するか，印
刷するかによって，印别物を美しくすることに着手

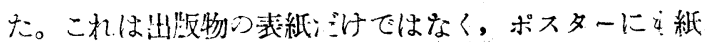
器類にも応用世られているが，ての材科としては各種 合成樹脂などが吏われている。例えば，油溶性の石炭酸 樹脂, アルキッド樹脂，尿素及びメラミン樹脂，ポリビ ニルアセテート, アクリル樹脂, ポリビニルブチラール,

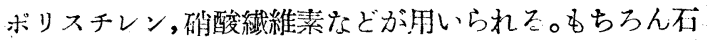
炭酸樹脂凤場合には，ビスフェノールのよ5なるのを使 用するのがよく，これによって高粘度, 高融点のものが 得られるからオーバープリント用として好適で昰呑。戦

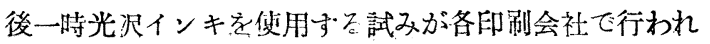
オーパープリントの手数をはぶこらとしたが，紙質と印 刷インキがー致しない為、吸收变の高、紙には応用が困 難であった。殊にわが国では，紙質を一定にすることが むつかしいので, 時によつては，光次の安印刷物が得 られるかと思えば，時によっては全然強光次インキの価 值が認められなかった。その結果オーバープリントが非 常に奖用される結果となった。以上述べ来ったよらに印 刷インキ朋として高分子物が使用せられるのは, 主とし てビヒクルについてであり，印别適性といら大きな条件 がこの選択を左右することに注目ずべきでまる。これが 篤, 適当な电系性, 弾性, 粘着性などの要素が考慮され なければならない。例えばある高分子物が塗料用ビヒク ルに応用せられて，その鉒料がらまく刷毛整りされたと しても，凸版や平版インキ用としては，必ずしも適当で ない場合が多い。しかして,ビヒクルとしての色, 光次, 乾燥度, 耐薬品性, 耐乳化性, 舁気, 透明度なと種々の 要求され条件を满足させるものが採用されることにな る。印别インキ用ビヒクルの材料として, 多数の新しく 発見される高分子物について，これらの研究がどんどん 行われて，できるだけすみやかに印别インキの分野に採 り入れられることを望むと共に，印别インキの研究者と 高分子化学の研究者とが，よく連繫を密にして研究を進 めで行くことが，この目的を達成するはや道であること を痛感するものである。（大日本インキ製造株式会社）

\section{文・献}

1）市川家康；印刷インキの粘弾性 印刷庁研究所時報 第 3 巻第 10 号 $\mathrm{p} 19$

Lars Sjodahl, TALI Proceedings 1949 and American Ink Maker Vol, 39, No.3, p.31 33 ‘ 57, March (1951)

Andries Voet, TALI Proceedings

2) Henry Green, Industrial Rheology and Rheological Structures p91 (1949)

3) H. F. Payne, L. E. Cadwell, R. H. Brailey, A. F. Schmutzler American Mk Maker Dec. p23 (1947), Jan p28 (1948), Feb. p27 (1948)

4) H. J. Wolfe, Printing and Litho Inks p317 (1949) 